\title{
A heuristic framework for voice instruction at the doctoral level
}

\author{
Alet Olivier \\ Academic Literacy Consultant, Bloemfontein, South Africa \\ E-mail: alet.olivier@gmail.com \\ Adelia Carstens \\ Unit for Academic Literacy, University of Pretoria, South Africa \\ E-mail: adelia.carstens@up.ac.za
}

\begin{abstract}
The notion of voice as an integral aspect of language use has been extensively theorised in linguistics. However, empirical research and pedagogical models have not yet matched the sophistication of voice theories in linguistics, and little attention has been paid to advanced academic writing. This article attempts to address two pertinent gaps in the pedagogical and empirical literature: inadequate training of doctoral students to make an authentic contribution to knowledge creation in their respective fields, of which a distinctive authorial voice is a criterial feature; and bridging the gap between theory and practice. An account is given of two theoretical models of voice - both embedded in Systemic Functional Linguistics - that have served as the basis of the majority of instruments aimed at concretising the somewhat elusive notion of voice. An overview is given of existing heuristics of voice designed by other scholars, followed by the presentation and description of a self-developed and comprehensive heuristic framework for voice that may inform the development of instructional toolkits for doctoral students.
\end{abstract}

Keywords: academic writing; doctoral writing; metadiscourse; pedagogy of voice; stance and engagement

\section{Introduction}

The notion of voice has been extensively theorised in socio-constructivist linguistic theories, notably in Systemic Functional Linguistics (SFL), which constitutes the basis of the Appraisal Framework (Martin and White 2005) and models of Metadiscourse (Hyland 2008). The interest in voice as a component of writing practices originated during the 1970s in L1 composition writing in the USA around a focus on authorial identity and self-expression, labeled authentic voice. Between the 1970s and the 1990s voice was established as one of the principles that guided L1-dominant American school and university writing, and served as a fundamental impetus in the development of writing instruction (Matsuda 2001). Scholarly publications on 
academic writing in the new millennium witnessed a revived interest in voice (Elbow 2007; Helms-Park and Stapelton 2003; Hyland 2007, 2008; Matsuda 2015; Matsuda and Tardy 2007; Tardy 2016; Zhao 2013), and demonstrated a marked shift away from the predominantly expressivist and personalised pre-2000 approach to writing (Yeh 2015), and moved towards a perspective that recognises the importance of both individualised and socialised voice (multivoicedness).

However, empirical research and pedagogical models have not yet matched the sophistication of voice theories in linguistics (Canagarajah 2015), and little attention has been paid to advanced academic writing, where demonstrating a unique authorial voice constitutes one of the primary criteria for the successful completion of a thesis. The next section sketches the context of doctoral writing, with particular emphasis on the South African context.

\section{The context of doctoral writing}

The global increase in the number of speakers of English as an Additional Language (EAL), coupled with the massification of higher education worldwide, and the status of English as the internationally accepted language of research and publication, have resulted in a heterogeneous group of writers whose diverse language and writing needs have to be met (Hyland 2013; Lillis 2003). In the case of higher degrees, especially doctoral degrees, the stakes are high to master academic English to the level where a distinct scholarly voice can be demonstrated. In particular, the doctoral thesis is expected to make a "substantial and original contribution to knowledge" (Wellington, Bathmaker, Hunt, McCulloch and Sikes 2005:14). However, the writing attempts of doctoral students are often described by their supervisors as lacking depth, and as mere reproductions of the work of highly regarded scholars (Basturkmen, East and Bitchener 2014; Ivanič 1998; Kamler and Thomson 2006). Also, doctoral students themselves are uncertain about how to express their educational identity (Schulze 2014), which is a compound notion comprising epistemological and empirical knowledge that is inextricably bound to the intertextual practices of the scholarly community, as well as to the student's personal identity.

Universally, the need for assistance with writing has grown linearly with the growth in the number of doctoral studies produced during the past two decades (Kamler and Thomson 2006:9). Where writing assistance is generally available to undergraduate students, the teaching of writing at a postgraduate level is rare or lacking. A lack of, and a need for, formal training in doctoral writing has been highlighted (in chronological order) by Paltridge (2003), Swales (2004), Boote and Beile (2005:5), Kamler and Thomson (2006:10), Starfield and Ravelli (2006), San Miguel and Nelson (2007), Kamler (2008), Cotterall (2011), Guerin and Picard (2012), and Basturkmen, East and Bitchener (2014).

In comparison with Western countries, the production of doctoral degrees in South Africa is extremely low. In 2007 South Africa produced 26 doctorates per million of the total population compared to 28 per million in Mexico, 201 in the USA, 264 in Australia, 288 in the UK and 569 in Portugal. Three recent reports provide useful statistics, interpretations of and recommendations on doctoral education in South Africa and shed light on the need for the holistic advancement of doctoral studies, in particular with regard to writing: The Academy of Science of South Africa (ASSAf) Report (2010); Doctoral education in South Africa: Policy, discourse and data (Cloete, Mouton and Sheppard 2015); and the Higher Education Monitor's 
edition on The state of higher education in South Africa (Council on Higher Education 2009). One of the recommendations of the ASSAf Report to improve throughput is that doctoral students should develop "skills such as writing and publishing" (ASSAf 2010:77).

This article attempts to address the gaps outlined in the previous two sections, namely the theory-practice divide and the inadequate training of doctoral students in developing a distinctive authorial voice. First, a summarised account is given of the theoretical models of voice that have served as the basis of the majority of instruments aimed at concretising the somewhat elusive notion of voice. This is followed by an overview of existing instruments designed by other scholars, and a more detailed description of a heuristic ${ }^{1}$ framework developed by the first author as part of her doctoral thesis (Olivier 2017a). The article is concluded by recommendations on the further operationalisation of this set of heuristics at lower levels of abstraction and with domain-specific foci.

\section{Dominant models of voice in Applied Linguistics}

Two models, both embedded in socio-constructivism, and drawing heavily on Systemic Functional Linguistics (SFL), have been used extensively in the operationalisation of voice at different levels and in a variety of instruments, such as rubrics, rating scales and heuristics. These models are the Engagement Framework, which forms part of Martin and White's (2005) Appraisal Framework, and Hyland's model of Metadiscourse (2004b, 2005a, 2008, 2010). Next, an overview is given of these two frameworks, as synthesised from a range of scholarly sources.

\subsection{Martin and White's Engagement Framework}

The Appraisal approach is a functional model of language and social context that developed from the general theoretical framework of SFL, as expounded in Halliday's Language as a social semiotic (1978) and An introduction to functional grammar (1985). The Appraisal Framework was initially developed from a focus on media discourse (Martin and White 2005:xi), looking "in particular at the bonding of appraisal with ideational meaning in the fields of history and the print media" (2005:28); however, the primary impetus for its development as "a typology of evaluative resources available in English" (Hyland 2005b:174) was provided by the "Write it Right Project" of the New South Wales (NSW) Disadvantaged Schools Programme during the 1980s and 1990s.

Appraisal is located as an interpersonal system at the level of discourse semantics (Martin and White 2005:33) and is concerned with the linguistic resources by which writers may assume intersubjective positions towards the propositions in their texts and negotiate with their interlocutors. Three interacting subtypes have been distinguished, viz. attitude, engagement and graduation. Attitude is concerned with feelings, including emotional reactions, judgements of behaviour and evaluation of things (see Martin and White 2005:51-91 for a full exposition of judgement and appreciation). Engagement has to do with the ways in which writers position themselves with respect to potential responses by acknowledging, denying, countering or affirming possibilities, or by quoting and reporting. Graduation deals with gradability in terms

\footnotetext{
1 "Heuristic" serves as a cover term for a set of guidelines used to facilitate discovery by learners or investigators. Theoretically, a heuristic framework may be a precursor of a model, and practically, heuristics may be utilised for analytical, descriptive and instructional purposes.
} 
of the writer's intensity or investment in the utterance (force) - force expresses the degree of intensity or amount (e.g. slightly, greatly, very, completely); and the sharpening or softening of attitudes (focus) (Martin and White 2005:138). Table 1 is a schematic representation of the Appraisal Framework.

Table 1: Schematic layout of the Appraisal Framework (adapted from Martin and White 2005:38, 32-61, 97-135,138,141)

\begin{tabular}{|c|c|c|c|c|c|c|}
\hline \multirow{12}{*}{\multicolumn{2}{|c|}{ E }} & \multirow{3}{*}{ Affect } & Affect as quality & & & \\
\hline & & & Affect as process & & & \\
\hline & & & $\begin{array}{l}\text { Affect as } \\
\text { comment }\end{array}$ & & & \\
\hline & & \multirow[b]{3}{*}{ Judgement } & \multirow[t]{2}{*}{ Modalisation } & Probability & & \\
\hline & & & & Usuality & & \\
\hline & & & Modulation & Obligation & & \\
\hline & & & & \multirow[t]{2}{*}{ Readiness } & Inclination & \\
\hline & & & & & Ability & \\
\hline & & \multirow{4}{*}{ Appreciation } & & \multirow{4}{*}{$\begin{array}{l}\text { Positive } \\
\text { and } \\
\text { Negative }\end{array}$} & $\begin{array}{l}\text { Mental } \\
\text { process type: }\end{array}$ & Meta-function: \\
\hline & & & Reaction & & Affection & Inter personal \\
\hline & & & Composition & & Perception & Textual \\
\hline & & & Valuation & & Cognition & Ideational \\
\hline \multirow{5}{*}{$\begin{array}{l}\frac{1}{\alpha} \\
\frac{\alpha}{0} \\
\frac{1}{2} \\
\frac{1}{2}\end{array}$} & \multirow{10}{*}{ 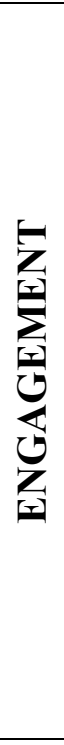 } & Monogloss & $\begin{array}{l}\text { Bare assertions; } s \\
\text { impersonal }\end{array}$ & vidently righ & d just, descript & e, report-like, and \\
\hline & & \multirow{9}{*}{$\begin{array}{l}\text { Heterogloss: } \\
\text { dialogic }\end{array}$} & \multirow{6}{*}{ Contract } & \multirow[b]{3}{*}{ Disclaim } & & Examples \\
\hline & & & & & Deny & No, don't, never \\
\hline & & & & & Counter & $\begin{array}{l}\text { But, however, } \\
\text { unfortunately }\end{array}$ \\
\hline & & & & & Concur & $\begin{array}{l}\text { Indeed, naturally, } \\
\text { certainly }\end{array}$ \\
\hline 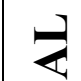 & & & & Proclaim & Pronounce & $\begin{array}{l}\text { Clearly, obviously, } \\
\text { already }\end{array}$ \\
\hline$\underset{\underline{\alpha}}{\underline{\alpha}}$ & & & & & Endorse & $\begin{array}{l}\text { Proves, } \\
\text { underscores, } \\
\mathrm{X} \text { has demonstrated }\end{array}$ \\
\hline$\frac{1}{4}$ & & & & Entertain & & $\begin{array}{l}\text { Probable, may, } \\
\text { seem }\end{array}$ \\
\hline & & & Expand & & Acknowledge & $\begin{array}{l}\mathrm{X} \text { argues, believes, } \\
\text { said, states }\end{array}$ \\
\hline & & & & Attribute & Distance & $\mathrm{X}$ claims, contends \\
\hline & & Force & & Quality & & $\begin{array}{l}\text { Slightly sad - very } \\
\text { sad }\end{array}$ \\
\hline & $\underline{\underline{0}}$ & & Intensification & Process & & $\begin{array}{l}\text { Slightly disturbed, } \\
\text { greatly disturbed }\end{array}$ \\
\hline & $\frac{2}{2}$ & & Quantification & & & $\begin{array}{l}\text { Small problem - } \\
\text { large problem; a } \\
\text { few problems - } \\
\text { many problems }\end{array}$ \\
\hline & $\Xi$ & & Sharpen & & & A true father \\
\hline & & Focus & Soften & & & An apology of sorts \\
\hline
\end{tabular}

Voice is primarily concerned with the Engagement Framework, with its dialogical and communicative dimensions. The Engagement system deals with the linguistic resources available to writers to provide the means for the authorial voice to engage with other voices and 
to adopt alternative positions in the communicative context (Martin and White 2005:92, 94). The various choices exercised by authors create the appropriate rhetorical effect (Martin and White 2005:92). Table 2 below represents a multifaceted diagram of the Engagement Framework as described and illustrated in various figures in Martin and White (2005:104, 117, 122).

Table 2: The Engagement Framework of dialogic contraction and expansion (adapted from Martin and White 2005:104,117,122)

\begin{tabular}{|c|c|c|c|c|c|}
\hline \multicolumn{2}{|c|}{ Monogloss } & \multicolumn{4}{|c|}{$\begin{array}{l}\text { Bare assertions; self-evidently right and just, descriptive, report-like, and } \\
\text { impersonal; imperatives; common/shared knowledge }\end{array}$} \\
\hline \multirow{9}{*}{ 桌 } & \multirow{9}{*}{$\begin{array}{l}\text { Heterogloss: } \\
\text { dialogic }\end{array}$} & \multirow{6}{*}{ Contract } & \multirow{3}{*}{ Disclaim } & \multicolumn{2}{|r|}{ Examples } \\
\hline & & & & Deny & No, don't, never \\
\hline & & & & Counter & $\begin{array}{l}\text { But, however, } \\
\text { unfortunately }\end{array}$ \\
\hline & & & \multirow{3}{*}{ Proclaim } & Concur & $\begin{array}{l}\text { Indeed, naturally, } \\
\text { certainly }\end{array}$ \\
\hline & & & & Pronounce & $\begin{array}{l}\text { Clearly, obviously, } \\
\text { Already }\end{array}$ \\
\hline & & & & Endorse & $\begin{array}{l}\text { Proves, underscores, } \\
\mathrm{X} \text { has demonstrated }\end{array}$ \\
\hline & & \multirow{3}{*}{ Expand } & \multicolumn{2}{|l|}{ Entertain } & Probable, may, seem \\
\hline & & & \multirow[t]{2}{*}{ Attribute } & Acknowledge & $\begin{array}{l}\text { They argue, believe, } \\
\text { said, state }\end{array}$ \\
\hline & & & & Distance & They claim, contend \\
\hline
\end{tabular}

The first distinction made is between monogloss and heterogloss. Monogloss implies that writers use bare assertions without acknowledging alternative positions or voices, for example: The hard sciences are based on objective truths.

Heteroglossic utterances on the other hand invoke other voices and allow for alternatives in the discourse; in other words for multiple voices to enter into the conversation. The heteroglossic or dialogistic resources of the Engagement Framework are divided by Martin and White (2005:102) according to whether they serve to contract or expand a proposition dialogistically. Dialogistic contraction contracts the dialogistic communication of external voices by excluding or rejecting alternatives from engaging in the communication, while in dialogistic expansive utterances the authorial voice of the writer distances itself from a proposition in various ways. The two main categories of contraction are recognised by Martin and White (2005:117) as disclaim and proclaim. Disclaiming provides the writer with the opportunity to introduce a dialogic alternative, hence to acknowledge other possibilities, but then to reject or deny that alternative; or to offer the writer an opportunity to take a counter position (Martin and White 2005:120). Proclaim can take three alternative positions, viz. concur, pronounce and endorse. Whereas disclaiming formulations reject, overrule and offer counterarguments, proclaiming formulations are dialogistic in that the writer entertains a dialogue with the reader. Such formulations are contractive as they limit the scope of the dialogistic alternatives in different ways.

In the category of concur, the writer shows alignment with the reader as a discourse partner by agreeing with the writer's viewpoint and beliefs, and sharing his/her knowledge which is "so 
'commonsensical', that agreement can be taken for granted...[and]...from which dissident voices and positions are excluded" (Martin and White 2005:122, 124). Concur can take two forms: the one of affirmation by adverbs and conjunctions such as of course, admittedly, obviously; the other by concessions such as admittedly, sure, certainly. The subcategory pronounce refers to formulations that overtly involve authorial interpolations and emphases. These formulations acknowledge the heteroglossic diversity of positions, but at the same time confront, challenge or resist alternatives. It demonstrates a higher degree of overt intervention and authorial voice in the text than concur. The category of endorse has a dialogistic contracting function of alignment. This category is the counterpart of dialogistically expansive attributions (Martin and White 2005:126). The difference is that propositions are grounded in the writer and the internal voice takes responsibility for the propositions introduced in the text. The alignment function is increased by dint of a shared responsibility by external sources and the internal authorial voice of the writer. The reporting verbs express factivity, presuppose the writer's 'warrantability' and fulfil the function of intervening in the meaning-making together with external sources in purporting a proposition as proven or demonstrated, thus taking responsibility for the "rhetorical heavy lifting" (Martin and White 2005:126-7).

The other main category of dialogistic resources in the Engagement Framework is termed dialogistic expansion and falls into two categories, viz. entertain and attribute. The term entertain refers to the writer's internal authorial voice indicative of alternative positions that are entertained, thus recognising that the proposition entertained is but one amongst many other propositions available in the communicative context. In this regard the writer is strongly committed to a viewpoint. The other category of dialogistic expansion, attribution, involves voices from external sources but also provides the opportunity for the writer's authorial voice to engage with those external voices, thus emphasising dialogistic communication. Attribution is a known key feature in academic discourse. Martin and White (2005) subdivide attribution into two subsections, viz. acknowledge and distance. By recognising this distinction within attribution as being much more than a technical requirement of academic writing, often referred to as referencing or citation, the dialogistic nature of attribution is emphasised (see also Hyland 1999; Thompson 1996). Writers should make an informed dialogic choice in terms of where the authorial voice stands with respect to the proposition, or external voices employed in a text. When the author acknowledges other voices the reporting verb does not overtly endorse the proposition put forward by the external voice. In the other subcategory of attribution, that of distance, writers clearly distance themselves from the propositional content of the external voice(s) by employing distancing framers or reporting verbs, to stay unimplicated in the external voice and the propositional content proposed (Martin and White 2005:111-116).

We now turn to another model often used to analyse academic discourse in terms of stance and engagement, viz. Hyland's model of Metadiscourse (2005a, 2010a).

\subsection{Hyland's model of Metadiscourse}

Hyland's model of Metadiscourse (2005a, 2010) provides a broad canvas and analytical basis for models and empirical studies with a pedagogical intent, owing to its practical and pedagogical usefulness (Cheng and Steffensen 1996:170-180). The model pivots on writing as interactive and interactional, and provides "choices" for writers to address readers' expectations. 
Metadiscourse was initially characterised as "discourse about discourse" (Vande Kopple 1985:83) and "discoursing about discourse" (Crismore 1984:280); however, more recently, it has become an approach to writing as social engagement (Hyland 2005a:203). In this sense, metadiscourse is the way in which writers project themselves in their texts to engage with their readers, signal the writer's attitude (Amiryousefi and Rasekh 2010:159) and create a convincing and coherent text. In summary, metadiscourse became a cover term for linguistic mechanisms used to negotiate interactive and interactional meanings in a text (Hyland 2005a:37).

Similar to the Appraisal Framework, the theoretical foundation of metadiscourse is constituted of Halliday's (1994) classification of language into three broad metafunctions or purposes: the ideational, interpersonal and textual (Hyland 2005a:26). An essential defining principle of Halliday's metafunctions is the integration and interrelation of all three functions (Carstens 2009:37), unlike scholars, such as Crismore and Farnsworth (1990), Crismore, Markkanen and Steffensen (1993), Hyland (1998, 2000) and Vande Kopple (1985), who have also drawn on Halliday's three principles but have separated the textual, propositional and interpersonal elements of texts (Hyland 2005a:27).

Particularly noteworthy is the acceptance of metadiscoursal features within the conventions of doctoral writing. Starfield and Ravelli (2006) report on an influential qualitative case study of 20 (then) recent PhD theses in the Humanities. They present a case for the emergence of a "New Humanities $\mathrm{PhD}$ ", which portrays the construction of, amongst others, the reflective self in its macrostructures. These scholars explicitly draw attention to the metadiscoursal nature of contents pages which evidently "begin to construct and negotiate an identity for the writer and a location for the writer and his/her thesis within a research culture" (Starfield and Ravelli 2006:226). Other studies (viz. Richardson 2000; Turner 2003) have also marked a shift in knowledge construction in doctoral studies, which is affected by writing style and format "under the influence of postmodernism that signals a questioning of the assumed relationship between discipline and knowledge, of the "system... of doctorates"" (Hodge 1998 as cited in Starfield and Ravelli 2006:223).

Table 3 summarises the model of metadiscourse that Hyland proposed in various publications (1998, 2004a, 2005a, 2005b; 2008, 2010, 2017; Hyland and Tse 2004).

Table 3: A summary of Hyland's model of metadiscourse in academic texts (adapted from Hyland 2005a and 2005b)

\begin{tabular}{|l|l|l|l|}
\hline & \multicolumn{2}{|c|}{ CATEGORY } & \multicolumn{2}{c|}{ FUNCTION } & \multicolumn{1}{c|}{ EXAMPLES } \\
\hline \multirow{4}{*}{} & \multicolumn{2}{|c|}{ Features that are aids to guide the reader through the text } \\
\cline { 2 - 4 } & $\begin{array}{l}\text { Transition/logical } \\
\text { connectors }\end{array}$ & $\begin{array}{l}\text { Express relations between main } \\
\text { clauses }\end{array}$ & In addition, but, thus, and \\
\cline { 2 - 4 } & Frame markers & $\begin{array}{l}\text { Refer to discourse goals, } \\
\text { sequences or stages }\end{array}$ & $\begin{array}{l}\text { Finally, to conclude, my purpose is, } \\
\text { first, second, last }\end{array}$ \\
\cline { 2 - 4 } & Endophoric markers & $\begin{array}{l}\text { Refer to information in other } \\
\text { parts of the text }\end{array}$ & Noted above, see fig; in section 2 \\
\cline { 2 - 4 } & Evidentials & $\begin{array}{l}\text { Refer to information from other } \\
\text { texts }\end{array}$ & According to X, Z states \\
\cline { 2 - 4 } & $\begin{array}{l}\text { Elaborate on propositional } \\
\text { meaning }\end{array}$ & $\begin{array}{l}\text { Namely, e.g., such as, in other } \\
\text { words }\end{array}$ \\
\cline { 2 - 4 } & Code glosses & \multicolumn{2}{|c|}{} \\
\hline
\end{tabular}




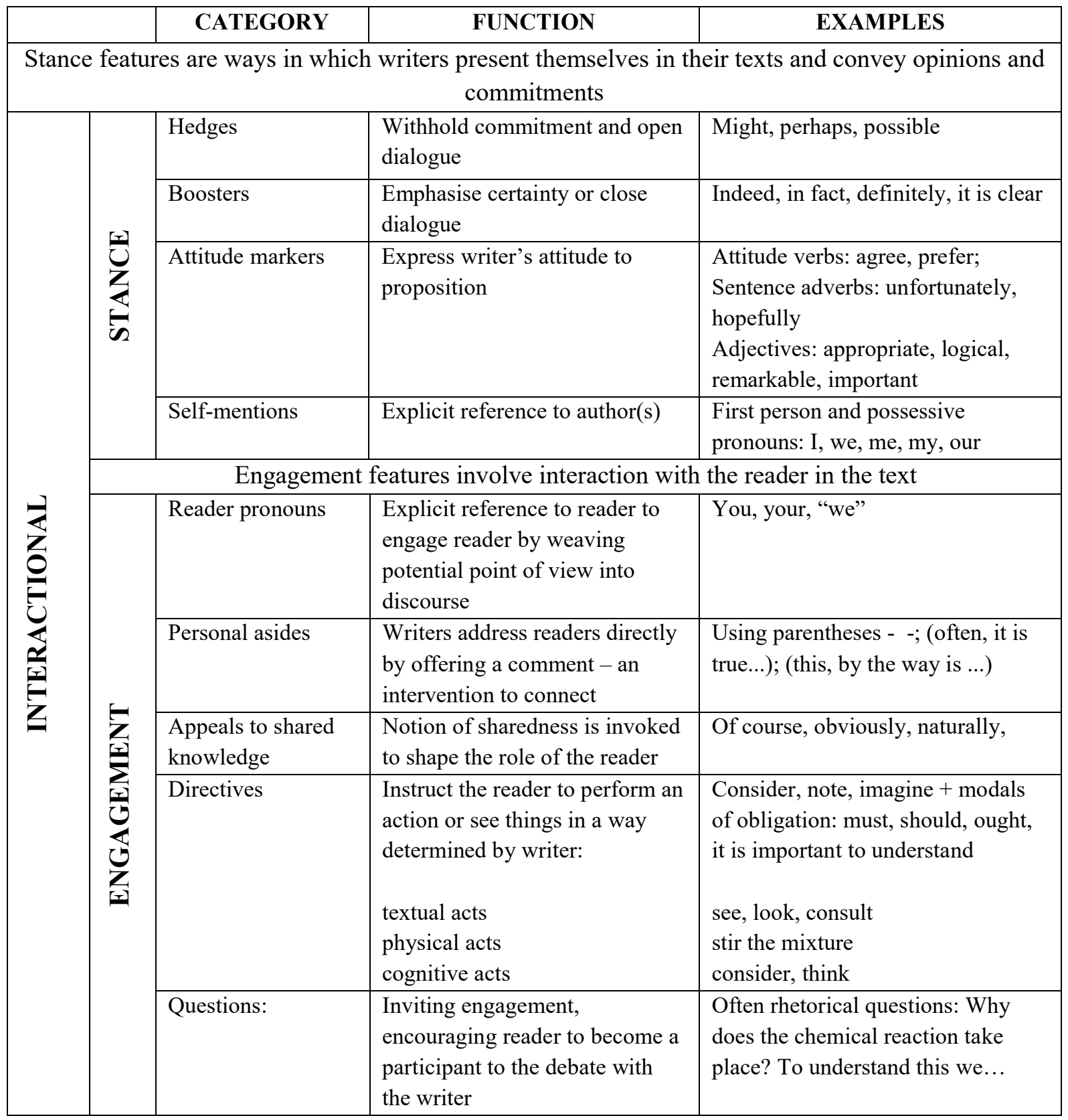

As can be read from the table, Hyland's model distinguishes between two main subclasses, namely interactive and interactional. The main purpose of the INTERACTIVE dimension is to shape and constrain a text and organise discourses in such a way as to guide the reader through the text. This dimension comprises five categories: Transitional markers, which have the function of conveying internal relations between main clauses and help the reader interpret links between ideas; Frame markers signal text boundaries and are used to sequence parts of the text, indicate topic shifts, indicate text stages or stipulate goals; Endophoric markers guide the reader to other parts of the text and make additional material or information available to the reader; Evidentials have the function of bringing information from other sources into the text by means of attribution or references and thus establish authorial command of the subject; and Code glosses explain, elaborate additional information or rephrase propositional content. 
The INTERACTIONAL dimension of Hyland's metadiscourse model can be managed by writers in two main ways, called stance and engagement (2005b, 2008). Stance, also referred to as "writer-oriented interaction" (Hyland 2008:9) and the "writer's textual voice or community recognised personality" (Hyland 2008:7) concerns the way in which writers present themselves and convey different kinds of opinions, attitudes, credibility assessments and commitments about propositional content. Stance comprises four elements: hedges, boosters, attitude markers and self-mention. Hedges fulfil the function of withholding complete commitment to a proposition, implying that a claim is not based on knowledge, but opinion. Thus hedges, as conflict avoidance strategy, open up a dialogical space for readers as discourse partners who can dispute or agree with interpretations. Boosters act as opposites of hedges in that they restrict or fend off alternative voices. They invoke solidarity with the reader by expressing certainty with regard to a proposition underlying the writer's conviction of an argument or position. Attitude markers realise affect. Attitude is often signalled by attitude verbs, attitude adjectives; and sentence adverbs. Self-mention denotes the presence of the writer, also called "discoursal self" (Ivanič 1998) in the text. Self-mentions project writers' stance and alignment in relation to their propositional content and arguments and in relation to the reader.

Engagement, also known as "reader-oriented interaction" (Hyland 2008:11), has an alignment function where writers can rhetorically acknowledge their readers as discourse partners. It fulfils a dual function of both seeking solidarity with the reader and influencing and preparing readers to consider propositions by anticipating possible objections. Hyland's (2008) model of engagement distinguishes between reader pronouns, personal asides, appeals to shared knowledge, directives, and questions. Reader pronouns are the counterpart of self-mention in the projection of stance. Reader pronouns explicitly make the reader visible. Personal asides also allow writers to address readers almost in the form of an interjection, an aside, actually confiding in the reader about something worthwhile mentioning. Writers apply directives in a text by means of imperatives or obligation modals that take three forms, viz. that of textual acts, physical acts or cognitive acts. Appeals to shared knowledge are constructions that build strong solidarity with readers by appealing to them to identify, share and accept the writer's proposition or arguments. Asking questions is a familiar way of involving an audience/reader. The questions that operate on the engagement level are mostly rhetorical questions which do not in the first place seek an answer but elicit the reader's attention and curiosity.

\section{The operationalisation of voice instruction: Overview of research}

An essential precondition to instructing voice is the operationalisation of the theoretical and abstract notion of voice (Canagarajah 2015; Chang 2010; Matsuda 2015) in ways that may guide pedagogical interventions. The instruments that may be designed to facilitate voice instruction include heuristics, rating scales and rubrics. It may be regarded as a logical first step to design a comprehensive heuristic framework for guiding the design and development of a range of instruments for instruction and assessment. However, in practice, the inverse has occurred: Particularly arising from the needs of teachers and undergraduate lecturers to quantify learners' mastery of voice, a range of dedicated assessment instruments has been designed. Below, an overview is given of the development of such instruments, and measurement of their effectiveness through empirical research. 


\subsection{Assessment instruments: Rubrics and rating scales}

A number of attempts have been made to investigate how authorial voice in written texts can be measured. Except for being descriptive scoring guides, an important function of rubrics is the powerful instructive element, described as "teaching tools that support student learning and the development of sophisticated thinking skills" (Andrade 2000:13). An advantage of developing more sophisticated rubrics and assessment indices is their contribution to a more robust conception of academic writing that "encompasses even those constructs that are not easily measured" (Matsuda and Jeffery 2012:162), including voice.

One of the most widely used rating scales is the Voice Intensity Rating Scale by Helms-Park and Stapleton (2003), which was applied to ESL freshman writing examples. It measured voice intensity in the categories of assertiveness, self-identification, reiteration of the central point, and authorial presence and autonomy of thought. Zhao and Llosa (2008) partially replicated Helms-Park and Stapleton's study using the Voice Intensity Rating Scale (2003) but, contrary to Helms-Park and Stapleton (2003), they observed a significant correlation between overall intensity and writing quality in L1 exit-level school writing assessment. Jeffery's (2010) study reports on results from voice criteria represented in high-stakes assessment rubrics from highschool-grade level in exit-level secondary direct writing assessments (DWA). The study illuminated three categories of voice: style, appropriacy and resonance. It was found that theory-based voice features do not lend themselves as well to compiling voice criteria as expressivist-functionalist criteria. DiPardo, Storms and Selland (2011) report on rubric development processes and cycles in refining a voice/stance rubric for the National Writing Project (NWP USA). The findings show the difficulties in designing an analytic scoring rubric, due to the elusive nature of voice. A significant contribution to the development and validation of an analytic rubric for voice is Zhao's (2013) mixed methods study on the pedagogical usefulness of a rubric based on Hyland's (2008) interactional model, which incorporates the individualistic facet of stance and the interdependent dimension of engagement.

Although these attempts at operationalising voice to measure student performance have contributed to creating pedagogical knowledge, we argue for the development of heuristics as an intermediate level of operationalisation that will, for instance, provide categories and codes for corpus analysis, themes and sub-themes for curricula, and scoring dimensions for assessment instruments, such as rubrics and rating scales. Next, an overview is given of existing sets of voice heuristics, followed by a proposal for a comprehensive heuristic framework, as presented by Olivier (2017a and 2017b).

\subsection{Voice heuristics}

A number of studies have attempted to design voice heuristics from different theoretical perspectives and academic levels in an effort to make linguistic resources explicit. Studies that involve operationalisations of Martin and White's (2005) Engagement Framework with a focus on textual features include Tang (2009), Hood (2012), Matsuda and Tardy (2007) and Canagarajah (2015), which are discussed in some detail.

Tang (2009:175) operationalised the Engagement system (Martin and White 2005) on the two differentiating levels of the "writer and specific (tutor) reader" and the "wider disciplinary community". She concomitantly applied an operationalised "metalinguistic toolkit" in 
analysing first year essays (Tang 2009:173, 181). Authority in student essays were evaluated on two interpersonal levels: the assertion of a writer's voice and locating the voice in the disciplinary conversation. Paring the notion of authority in writing and dialogism, Tang chose a slightly simplified set of strategies from the Engagement system in extending existing approaches to authority in undergraduate student essays, which is associated with maintaining voice in heteroglossic academic discourse. The category of dialogistic expansion is subdivided as 1) postulate (viewpoints presented as possibilities); 2) evidentialise (conveying the surface appearance of things); 3) hearsay (presenting a proposition voiced by undisclosed others); and 4) acknowledge (ideas attributed to an identified source). The category of dialogistic contraction included 1) pronounce (where writers emphasise their personal backing of an idea); 2) concurrence (where writers present an idea as uncontentious); and 3) endorse (where writers align or endorse a more authoritative source). Tang (2009) asserted the framing of evaluation and bearing responsibility in citation through the lens of dialogism as a new way to offer researchers and teachers a conceptually integrated approach to authority and voice in academic writing.

Hood (2012) identified ways in which configurations of the Appraisal Framework (Martin and White 2005), such as Engagement, Attitude and Graduation, could be operationalised and used for analysis of the academic research article genre, spearheading an approach "[f]rom theory to practice" (Hood 2012:57). She argued that Appraisal theory could be useful to evaluate discourse and provide a framework for interpreting choices as meaningful. Hood offered a cline of instantiation for evaluation, grounded in the Appraisal Framework as a global potential of the language of evaluative meaning-making. Next on the cline is voice as "key (register)", semiotic constructs that relate to the construal of identities in the language of texts through meaning-making options. Stance (text-type) is further down on the cline, representing subselections in the construction of authorial personae. Then "evaluation (text)" denotes instantiation of evaluative options in texts and, last on the cline, "reaction (reading)" exemplifies evaluative meanings subjectively determined by the listener/reader (Hood 2012:5455). Hood applied the semantic options for Graduation, as well as the visibility and projection of sources in the introductory sections of academic research writing.

Matsuda and Tardy (2007) and Canagarajah (2015) did not apply either of the two theoretical models discussed in this article as such. In Matsuda and Tardy's (2007) study on author identity in a blind manuscript review, Matsuda's (2001:40) benchmark definition of voice forms the basis of the interpretation of voice constructed by the reader, in particular the overall impression of the text: "Voice is the amalgamative effect of the use of discursive and non-discursive features that language users choose, deliberately or otherwise, from socially available yet everchanging repertoires". Although the engagement with the reader, who discerns voice, is a crucial element of the social aspect of voice, features distinguished in such a way are too vague and fluctuating to apply as determining and guiding features of voice. A journal article on rhetoric and composition was analysed by two blind reviewers, who discerned the following features: reviewer 1) scope of the manuscript, choice of journal, (mis)use of terms, rhetorical moves, representation/positioning of other scholars in the, field, breadth of knowledge, gaps in sustained style, syntax, careful editing; reviewer 2: demonstrated knowledge of topic and conversation, theoretical lens, personal growth/revelation, a gender/race lens, rhetoric moves/representation of the field, citations, (un)awareness of full implications of argument, syntax, concision, mechanics (Matsuda and Tardy 2007:243). Although the study provides valuable research on how readers construct authors' voice in academic texts, this method relies 
on an impressionistic assessment of the reader in determining voice and is even more difficult to conceptualise as universal and tangible guidelines, than discernible textual features.

Although Canagarajah's (2015) heuristic for voice analysis was built upon dominant theoretical constructs, he distilled a heuristic focusing on the interrelationship between identity, role, subjectivity, and awareness in the voices of multilingual students to examine how the "amalgamative effect" (Matsuda 2001:40) of voice features is negotiated between the reader, the text and the writer. This heuristic was designed so that "teachers can explore how students may negotiate constraint and agency, determinism and autonomy, and ascribed and acquired identities". He concomitantly applied his heuristic by co-constructing and negotiating his role as instructor (supervisor) of a Master's literacy autobiography. One of the important outcomes of his study for this article and for ongoing research is that dialogical pedagogy facilitates negotiations on two levels, firstly in helping students negotiate their layers of voice and secondly the level of facilitating negotiations.

\subsection{Proposed heuristic framework for voice in academic texts}

Olivier (2017a) proposed a unified heuristic framework that would bring writing scholars closer to a comprehensive pedagogy of voice. The framework was intended to be appreciative of the importance of choice in the construction of meaning, and to encompass a range of linguistic features relevant to voicing possibilities in different kinds of texts. It draws on both Martin and White's (2005) Engagement Framework (which is part of the Appraisal Framework) and Hyland's model of Interpersonal Metadiscourse (2004b, 2005a, 2008, 2010).

Hyland's (2008) metadiscoursal model of stance and engagement, which is discussed in Section 3.2 , served as the basis of the heuristic framework proposed in this article. Hyland's metadiscoursal model was found to be particularly useful, as it was designed from corpus-based studies to serve as a guideline for advanced academic writing. Another important feature of Metadiscourse is its interactive dimension (Hyland 2005a, 2005b), which serves as an aid to guide the reader through a text. These features have been re-labelled in the heuristic framework as organisational markers of INTRATEXTUAL DIALOGIC VOICE.

Martin and White's (2005) Engagement Framework was used to augment Hyland's model of Metadiscourse. An important feature is its emphasis on academic discourse as a matter of choice, also referred to as dialogistic positioning, which links back to Bakhtin's (1981) heterogloss and multivoicedness. Students should be made aware of the range of intertextual voicing possibilities at their disposal. A limitation of the model is that the category of evidentials (in the interactive dimension) is, in our view, underdeveloped. This deficit may be attributed to Hyland's view that Metadiscourse excludes propositional content (Hyland 2005a:38).

The array of engagement resources that Martin and White (2005) include in their framework is indicative of the complex discoursal level at which writers have to negotiate meanings in academic writing. However, the model has been found lacking in that the Engagement Framework operates at a fairly high level of abstraction, and consequently is still a theory about how stance and engagement works in language, particularly in media discourse. The reason why the Engagement Framework has been subsumed under the headings DIALOGISTIC CONTRACTION and DIALOGISTIC EXPANSION, is that citation and acknowledgement are 
vital to argumentation at the doctoral level, as indicated by Matsuda and Tardy (2007:244), and indirectly to Bakhtin's heteroglossia.

The heuristic framework for voice is represented in Figure 1 below.

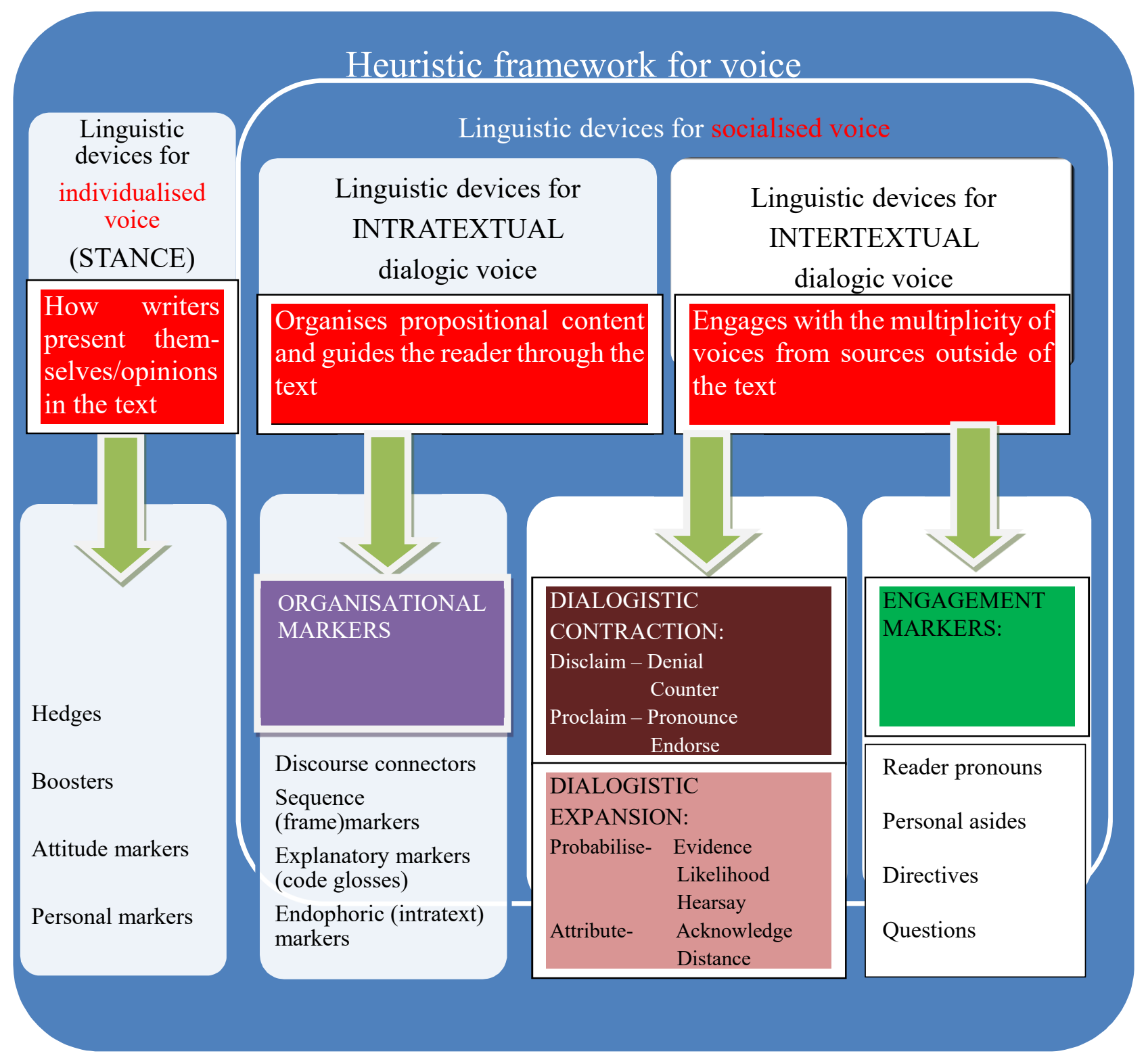

Figure 1: A heuristic framework proposed for voice in academic writing

The main categories of the framework can be motivated as follows: two main categories are distinguished: the first main category is LINGUISTIC DEVICES FOR INDIVIDUALISED VOICE in academic writing, and the second is called LINGUISTIC DEVICES FOR SOCIALISED VOICE. The second category is further divided into two subcategories: LINGUISTIC DEVICES FOR INTRATEXTUAL DIALOGIC VOICE and LINGUISTIC DEVICES FOR INTERTEXTUAL DIALOGIC VOICE. 
The first category represents INDIVIDUALISED VOICE, also well-known as stance. These linguistic devices provide ways in which writers project themselves into the text to convey their judgements, opinions and commitments. They signify a writer's unique and recognisable imprint associated with authorial presence in the text and signifies how far writers establish an authorial presence in their writing. These devices have been labelled differently by different writers, for example in Ivaničian (1998:26) terminology it is known as the "self as author".

The second main category accommodates the broad category of LINGUISTIC DEVICES FOR SOCIALISED VOICE in academic writing. This category falls into two further categories, distinguishable as linguistic devices for INTRATEXTUAL DIALOGIC VOICE and linguistic devices for INTERTEXTUAL DIALOGIC VOICE. Writing is always both subject to and a result of social contexts. Socialised voice is associated with the disciplinary and other social groups with which the writing and the writer are inevitably interlinked. This kind of socialised voice is established as a result of writers' choices from certain discourses to align their work with particular texts and authors (Tardy 2012:37,38). These linguistic devices can be paralleled with Ivanič's (1998) widely used "discoursal self" and "possibilities for selfhood". They are the ways in which writers apply linguistic resources to guide the reader's interpretation of the socially conditioned positions with which they aligned themselves regarding disciplinary texts, authors, genre and audience. INTERTEXTUAL DIALOGIC VOICE refers to the multiplicity of voices outside of the text.

LINGUISTIC DEVICES FOR INTRATEXTUAL DIALOGIC VOICE in academic writing organise propositional content and aim to guide the reader through the organisation of the text. The functions are organisational and not argumentative or rhetorical like the engagement markers. These devices are categorised by Hyland (2005a and 2005b) as "interactive features". These devices include discourse connectors, sequence markers, explanatory markers (Hyland's "code glosses") and intratext (endophoric) markers.

LINGUISTIC DEVICES FOR INTERTEXTUAL DIALOGIC VOICE refers to the multiplicity of voices from sources drawn from outside the text and integrated in the text. Two subcategories are distinguished: dialogistic contraction and dialogistic expansion. Examples of lexicogrammatical markers for dialogistic contraction and expansion provide for the positioning of the writer towards all the voices entertained intertextually, thus only referring to the third person (singular or plural). The devices can either dialogistically expand or contract the writer's argument and position. Dialogistic contraction can be in the form of disclaiming (e.g. deny, concede) or proclaiming (concur, pronounce or endorse). When applying dialogistic expansion, as discussed above, the authorial voice distances itself, declines, separates or stays unconnected from the external voice and the propositional content proposed (Martin and White 2005:111-116). It can be presented through either probabilising (in the form of evidence, probability or hearsay) or attribution (by neutral acknowledgement or averral by distancing).

The second category of LINGUISTIC DEVICES FOR INTERTEXTUAL DIALOGIC (writerreader) VOICE in academic writing deals with writer-reader engagement. It represents the communication with, and rhetorical positioning of, the reader. These devices are used to underscore the interaction between the writer and the reader, resulting in co-construction of voice. Only the second person singular or plural is thus used in reader pronouns, personal asides, the imperative form in directives (relational markers) and in (rhetorical) questions to address the reader. 
A more detailed operationalisation that includes expanded tables of the purpose of each available linguistic device with examples of lexico-grammatical markers could not be included in this article, due to limit restrictions (see Olivier 2017a; 2017b). Although a more extensive framework than the mentioned heuristics developed from theoretical perspectives and halfoperationalised models, this framework, however, does not yet qualify as a fully operationalised model of voice, or a pedagogy of voice (Olivier 2017b: 284), as it still has to be validated. It is rather an attempt to tie together theoretical concepts of voice and previously operationalised models. The framework does not claim to instantiate a directive pedagogy but aims to propose a framework of voice for postgraduate, in particular doctoral students, supervisors, educationists and practitioners as a starting point to negotiate voice on postgraduate academic writing levels. Since linguistic terminology, as found in the Engagement framework and Hyland's (2008) stance and engagement model, has already been applied and validated on postgraduate as well as undergraduate writing levels in examples discussed above, this proposed heuristic framework for voice can contribute towards establishing the construct of voice in academic writing as a post-millennium pedagogical framework.

\section{Conclusion}

Voice has not only become acceptable in academic writing but has been welcomed as a nonnegotiable aspect of writing. Although the importance of voice in advanced academic writing is not disputed in the scholarly literature, guidelines and strategies on how voice can be acquired are in short supply. Empirical research on the necessity of the facilitation and instruction of voice has fuelled further research into the viability of a pedagogy for voice. A predominantly expressivist and individualist approach made way for an approach that embraces both the identity of the writer and the multiple voices contributed by other texts and other authors embedded in a climate of decoloniality, empowerment and social justice. The goal of a pedagogy of voice at the doctoral level is to empower, in particular students from disadvantaged educational backgrounds in South Africa who are in the process of obtaining higher degrees through medium of EAL, as is prevalent in the South African higher education setting.

Though the possibility of teaching voice is envisaged, the dilemma of execution lies, among other issues, in the misalignment between theory and practice: voice is over-theorised and under-operationalised. At the core of this disparity is the scarcity of operationalised instruments, such as rubrics, models and/or heuristics, without which the very complex, abstract construct of voice cannot be instructed. A number of empirical studies have attempted to operationalise theory in the format of heuristics that approach the ultimate goal of practical instruments, such as curricula, usage manuals and assessment instruments. However, none of these combine the two dominant models derived from Systemic Functional Linguistics. Although politically sensitive approaches, such as the New Literacy Studies and Academic Literacies, are implied in the broad idea of a set of heuristics, future research should consider adding explicit transformative dimensions. One strategy could be to build a large corpus of writing by doctoral students from diverse backgrounds, analyse these texts for differences in the operationalisation of voice, and possibly adapt the set of heuristics on the basis of the empirical evidence. Furthermore, the heuristics should be converted to domain-specific and student-friendly strategies and toolkits to further demystify voice in academic writing for students, supervisors, writing instructors and writing facilitators, for example through 
instructional manuals that contain self-assessment exercises, workshop-ideas, and appended by subject-specific and level-appropriate annotated or colour-coded texts.

\section{References}

Andrade, H.G. 2000. What do we mean by results? Using rubrics to promote thinking and learning. Educational Leadership 57(5): 13-18.

Amiryousefi, M. and A.E. Rasekh 2010. Metadiscourse: Definitions, issues and its implications for English teachers. English Language Teaching 3(4): 159-167.

ASSAf - Academy of Science of South Africa. 2010. Consensus report. The PhD study: An evidence-based study on how to meet the demands for high-level skill in an emerging economy. Available from https://www.assaf.org.za/files/2010/11/40696-Boldesign-PHD-small.pdf [Accessed on 12 April 2017].

Basturkmen, H., M. East and J. Bitchener. 2014. Supervisors' on-script feedback comments on drafts of dissertations: Socialising students into the academic discourse community. Teaching in Higher Education 19(4): 432-445.

Boote, D.N. and P. Beile. 2005. Scholars before researchers: On the centrality of the dissertation literature review in research preparation. Educational Researcher 34(6): 3-15.

Canagarajah, A.S. 2015. 'Blessed in my own way': Pedagogical affordances for dialogical voice construction in multilingual student writing. Journal of Second Language Writing 27: 122-139.

Carstens, A. 2009. The effectiveness of genre-based approaches in teaching academic writing: Subject-specific versus cross-disciplinary emphases. Unpublished $\mathrm{PhD}$ dissertation. Pretoria: University of Pretoria.

Chang, P. 2010. Taking an effective authorial stance in academic writing: Inductive learning for second language writers using a stance corpus. Unpublished $\mathrm{PhD}$ dissertation, University of Michigan. Ann Arbor.

Chang, P. and M. Schleppegrell. 2011. Taking an effective authorial stance in academic writing: Making the linguistic resources explicit for L2 writers in the social sciences. Journal of English for Academic Purposes 10(3): 140-151.

Cheng, X. and M. Steffensen 1996. Metadiscourse: A technique for improving student writing. Research in the Teaching of English 30(2): 149-181.

Cloete, N., J. Mouton J. and C. Sheppard. 2015. Doctoral education in South Africa: Policy, discourse and data. Cape Town: African Minds. Available from http://www.africanminds.co.za/wp-content/uploads/2015/11/Doctoral-Education-in-SouthAfrica-WEB.pdf [Accessed on 10 May 2017]. 
Council on Higher Education. 2009. Higher education monitor: The state of higher education in South Africa. HE Monitor No. 8. Available from: http://www.che.ac.za/sites/default/files/ publications/Higher_Education_Monitor_8.pdf [Accessed on 10 May 2017].

Cotterall, S. 2011. Doctoral students writing: Where's the pedagogy? Teaching in Higher Education 16(4): 413-425.

Crismore, A. 1984. The rhetoric of textbooks: Metadiscourse. Journal of Curriculum Studies 16(3): 279-296.

Crismore, A. and R. Fansworth. 1990. Metadiscourse in popular and professional science discourse. In W. Nash (ed.). The writing scholar: Studies in academic discourse, Newbury Park, CA: Sage.

Crismore, A.R. Markkanen and M. Steffensen. 1993. Metadiscourse in persuasive writing: A study of texts written by American and Finnish university students. Written Communication 10(1): 39-71.

DiPardo, A., B.A Storms and M. Selland. 2011. Seeing voices: Assessing writerly stance in the WP analytic writing continuum. Assessing Writing 16: 170-180.

Elbow, P. 2007. Voice in writing again: Embracing contraries. College English 70(2): 168-188.

Guerin, C. and M. Picard 2012. Try it on: Voice, concordancing and text-matching in doctoral writing. International Journal for Educational Integrity 8(2): 34-45.

Palgrave: Macmillan.

Halliday, M.A.K. 1978. Language as a social semiotic. London: Edward Arnold.

Halliday, M.A.K. 1985. An introduction to functional grammar. London: Edward Arnold.

Halliday, M.A.K. 1994. An introduction to functional grammar. (2 ${ }^{\text {nd }}$ edition). London: Edward Arnold.

Helms-Park, R. and P. Stepleton. 2003. Questioning the importance of individualized voice in undergraduate L2 argumentative writing: An empirical study with pedagogical implications. Journal of Second Language Writing 12(3): 245-265.

Hood, S. 2012. Voice and stance as appraisal: Persuading and positioning in research writing across intellectual fields. In K. Hyland and C.S. Guinda (eds.). Stance and voice in written academic genres. Palgrave: Macmillan.

Hyland, K. 1998. Persuasion and context: The pragmatics of academic metadiscourse. Journal of Pragmatics 30: 437-455.

Hyland, K. 1999. Academic attribution: Citation and the construction of disciplinary knowledge. Applied Linguistics 20(3): 341-367. 
Hyland, K. 2000. Disciplinary discourses: Social interactions in academic writing. Harlow, UK: Longman.

Hyland, K. 2004a. Disciplinary discourses: Social interactions in academic writing. Michigan: The University of Michigan Press.

Hyland, K. 2004b. Disciplinary interactions: Metadiscourse in L2 postgraduate writing. Journal of Second Language Writing 13: 133-151.

Hyland, K. 2005a. Metadiscourse. London: Continuum.

Hyland, K. 2005b. Stance and engagement: A model of interaction in academic discourse. Discourse Studies 7: 173-192.

Hyland, K. 2007. Genre pedagogy: Language, literacy and L2 writing instruction. Journal of Second Language Writing 16: 148-164.

Hyland K. 2008. Disciplinary voices: Interactions in research writing. English Text Construction 1(1): 5-22.

Hyland, K. 2010. Metadiscourse: Mapping interactions in academic writing. Nordic Journal of English Studies. Special Issue on Metadiscourse 9: 125-143.

Hyland, K. 2013. Writing in the university: Education, knowledge and reputation. Language Teaching 46: 53-70. Available from http://journals.cambridge.org/abstract_S0261444811 $\underline{000036}$ [Accessed on 3 June 2014].

Hyland, K. 2017. Metadiscourse: What is it and where is it going? Journal of Pragmatics, 113: 16-29.

Hyland, K. and P. Tse. 2004. Metadiscourse in academic writing: A reappraisal. Applied Linguistics 25(2): 156-477.

Ivanič, R. 1998. Writing and identity: The discoursal construction of identity in academic writing. Amsterdam: John Benjamins.

Kamler, B. 2008. Rethinking doctoral publication practices: Writing from and beyond the thesis. Studies in Higher Education 33(3): 283-294.

Kamler, B. and P. Thomson. 2006. Helping doctoral students write: Pedagogies for supervision. New York: Routledge.

Lillis, T.M. 2003. Student writing as 'Academic Literacies': Drawing on Bakhtin to move from critique to design. Language and Education 17(3): 192-207.

Martin, J.R. and P.R.R. White. 2005. The language of evaluation: Appraisal in English. New York: Palgrave Macmillan. 
Matsuda, P.K. 2001. Voice in Japanese written discourse: Implications for second language writing. Journal of Second Language Writing 10(1-2): 35-53.

Matsuda, P.K. and J.V. Jeffery. 2012. Voice in student essays. In K. Hyland and C.S. Guinda (eds.). Stance and voice in written academic genres. New York: Palgrave Macmillan.

Matsuda, P.K. 2015. Identity in written discourse. Annual Review of Applied Linguistics 35: 140-159.

Matsuda, P.K. and C.M. Tardy. 2007. Voice in academic writing: The rhetorical construction of author identity in blind manuscript review. English for Specific Purposes 26(2): 235-249.

Olivier, A.P. 2017a. Voice as a writing strategy in doctoral theses. PhD thesis. Pretoria: University of Pretoria.

Olivier, A.P. 2017b. Negotiating agency through authorial voice in thesis writing (Chapter 28). In S. Carter and D. Laurs (eds.). Giving Feedback on Research Writing: A Handbook for Supervisors and Advisors. London: Routledge.

Paltridge, B. 2003. Teaching thesis and dissertation writing. Hong Kong Journal of Applied Linguistics 8(2):78-96.

Richardson, L. 2000. Writing: A method of inquiry. In N.K. Denzin and Y.S. Lincoln (eds.). Handbook of qualitative research. $2^{\text {nd }}$ edition. Thousand Oaks CA: Sage. pp. 897-922.

San Miguel, C. and C.D. Nelson. 2007. Key writing challenges of practice-based doctorates. Journal of English for Academic Purposes 6(1): 71-86.

Schulze, S. 2014. Finding the academic self: Identity development of academics as doctoral students. Koers - Bulletin for Christian Scholarship 79(1). Available from http://dx.doi.org/ 10.4102/koers.v79i1.2114 [Accessed on 22 August 2015].

Starfield, S. and L.J. Ravelli. 2006. 'The writing of this thesis was a process that I could not explore with the positivistic detachment of the classical sociologist': Self and structure in New Humanities research theses. Journal of English for Academic Purposes 5: 222-243.

Swales, J.M. 2004. Research genres: Explorations and applications. New York: Cambridge University Press.

Tang, R. 2009. A dialogic account of authority in academic writing. In M. Charles, D. Pecorari and S. Hunston (eds.). Academic writing: At the interface of corpus and discourse. London: Continuum.

Tardy, C.M. 2012. Current conceptions of voice. K. Hyland and C.S. Guinda (eds.). Stance and voice in written academic genres. New York: Palgrave Macmillan.

Tardy, C.M. 2016. Voice in identity. In R.M. Machón and P.K. Matsuda (eds.). Handbook of second and foreign language writing (Vol 11). Berlin: Walter de Gruyter. 
Thompson, G. 1996. Voices in the text: Discourse perspectives on language reports. Applied Linguistics 17(4): 501-530.

Turner, J. 2003. Writing a PhD in the contemporary humanities. Hong Kong Journal of Applied Linguistics 8: 34-53.

Vande Kopple, W.J. 1985. Some exploratory discourse on metadiscourse. College Composition and Communication 36(1): 82-93.

Wellington, J., A. Bathmaker, C. Hunt, G. McCulloch and P. Sikes. 2005. Succeeding with your doctorate. London: Sage.

Yeh, S.-F. 2015. Mature Taiwanese writers' development of writing and voices between different academic environments. Advances in Language and Literary Studies 6(5): 197-208.

Zhao, C.G. 2013. Measuring authorial voice strength in L2 argumentative writing: The development and validation of an analytic rubric. Language Testing 30(2): 201-230.

Zhao, C.G and L. Llosa L. 2008. Voice in high-stakes L1 academic writing assessment: Implications for L2 writing instruction. Assessing Writing 13(3): 153-170. 